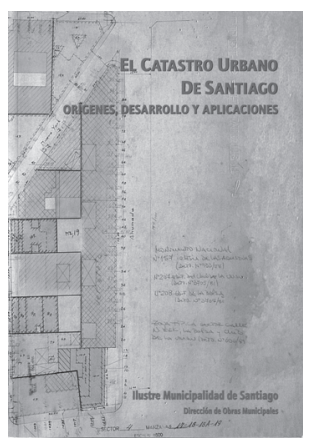

\title{
Dirección de Obras Municipales, Ilustre Municipalidad de Santiago. El catastro urbano de Santiago. Orígenes, desarrollo y aplicaciones
}

\author{
Santiago: Andros, 2008, 145 p.
}

\author{
Rafaella Monsalve ${ }^{1}$
}

\begin{abstract}
Han transcurrido más de 400 años desde la fundación de la ciudad de Santiago, lapso en el cual han ocurrido importantes transformaciones; naciendo, creciendo y desarroIlándose en un principio de forma espontánea, para luego expandirse en función de su centro. El catastro urbano histórico de la comuna de Santiago es un verdadero palimpsesto de la huella física sobre el territorio, desde la historia de la representación gráfica de la ciudad hasta la actualidad. El catastro urbano de Santiago: orígenes, desarrollo y aplicaciones, es un texto que desarrolla cuatro temáticas que evidencian la evolución histórica de la comuna.
\end{abstract}

Miguel Águila Sesser comienza el texto desde un punto de vista histórico universal sobre la importancia del catastro a nivel mundial y desarrolla el tema de los orígenes de este, pasando por las prácticas de catastros urbanos iniciales en las ciudades de las primeras civilizaciones de la antigüedad, destacando el uso y evolución de estos en ciudades europeas y algunas latinoamericanas. A continuación, José Ignacio González Leiva relata el modo en que la cartografía urbana, como identidad de las ciudades, permite la representación de sus características de emplazamiento y localización de hechos y fenómenos propios, a través del plano. Esta identidad se ha desarrollado desde la antigüedad clásica, pasando por la época medieval, el Renacimiento, el Barroco y variadas etapas hasta el siglo $\mathrm{XX}$, graficando

\footnotetext{
1 Estudiante de geografía que cursa su cuarto año de carrera. E-mail: rmonsalve@geo.puc.cl
}

por medio del arte del catastro las particularidades de cada ciudad, principalmente occidentales. González desarrolla esta gráfica heredada desde una mirada general sobre los orígenes y propiedades que cada plano ha tenido y va adquiriendo en las épocas posteriores de la cartografía urbana.

En la segunda sección, denominada la Ciudad de Santiago, Miguel Laborde Duronea explica la forma en que la ciudad nace, crece y se desarrolla de manera no planificada, desde el concepto histórico del catastro que viene a ordenar la expansión urbana por medio de la filosofía del orden que establece los límites de lo urbano y lo rural, lo público y lo privado, en una cultura de medir y acotar el espacio de interés redibujado en mapas, desplegando así los pensamientos filosóficos europeos de la cultura catastral. También intenta interpretar los cambios que ha adoptado este orden en la comuna a través de la historia, desde su ocupación en 1541, con la fundación y ocupación de Santiago, hasta principios del siglo XIX, explicando las transformaciones socioespaciales en las épocas de la Conquista, Colonia e Independencia de Chile. En esta segunda sección, Leonardo Espinoza Gho se encarga de mostrar la cartografía histórica de Santiago, desde la Colonia hasta el plano de Ansart. El hombre, en su afán de graficar lo que conoce de su entorno, elaboró la cartografía como información estratégica para el orden y dominio de las colonias americanas. Es por esto que la comuna de Santiago reconoce como una de sus primeras cartografías la realizada por el padre Alonso Ovalle en 1646, que representa a una ciudad ordena- 
da y estructurada. Fue así como lentamente se desarrollaron distintas representaciones gráficas de la ciudad para poder localizar espacialmente las características del entorno, dependiendo del fin que se le otorgase a la cartografía. El autor detalla los principales planos realizados en el siglo XIX, describiendo sus aportes, errores y resultados, en su mayoría similares en los trabajos realizados durante este periodo. Además, pone énfasis en el plano de Ansart como el inicio de una nueva era en la cartografía urbana nacional.

La tercera parte del libro aborda Santiago desde la escala de comuna y rescata la representación municipal en la ciudad. Ignacio Corvalán Rossel, en el primer texto de la sección, analiza el papel histórico de la Ilustre Municipalidad de Santiago sobre el catastro comunal. El crecimiento urbano experimentado en esta ciudad ha obligado a la actualización constante del plano de la comuna (encargado históricamente por intendentes), con el fin de obtener un orden y conocimiento auténtico de la ciudad. Por ello, el autor detalla la metodología utilizada para la elaboración del plano a través de la historia de la ciudad y se refiere al autor de cada plano. Destaca la función de los profesionales encargados de resolver esta materia, como Alejandro Bertrand, por su levantamiento y formación del plano de Santiago a fines del siglo XVIII; y Karl Brünner von Lehenstei, urbanista que establece el primer concepto de planificación de ciudad en forma global.

Álvaro Salas Rojas e Ignacio Corvalán Rossel son los encargados del segundo texto, abordando la importancia del catastro como huella de papel para la representación urbana de Santiago del siglo XX. Se adentran en la importancia del papel como modalidad histórica de la representación urbana en esta ciudad; desde los catastros hechos a principios del siglo XX hasta el día de hoy (con distintos propósitos), revisando para ello la base aerofotogramétrica. Reconociendo sus modalidades, se explican y comparan los diversos catastros realizados en la comuna de Santiago, describiendo cada identidad existente tras su elaboración y el fin que lo amerita.

La última sección aborda el problema del catastro actual en la comuna de Santiago; Gustavo Carrasco y Hugo Núñez desarrollan la metodología actual del proyecto de catastro digital de Santiago, definiendo sus objetivos, estrategias, levantamiento de datos, programas, sistemas, estructuras, puesta en marcha, gestión y administración. Para finalizar, Claudio Contreras, Raúl Ponce y Patricio Gigoux comentan el rol de las tecnologías de la información al servicio del catastro, desarrollando el modelo catastral, la lógica de interconexión de tablas, las tablas de enlace y la importancia de los Sistemas de Información Geográfica (SIG) para la operación de bases de datos y obtención de productos. Lo anterior, con el fin de construir un catastro multipropósito que siente las bases del ordenamiento y la toma de decisiones a nivel de gobierno local. Finalmente, se analizan los desafíos de la difusión catastral a escala académica, masiva, nacional e internacional, junto con los futuros retos para seguir avanzando en el catastro urbano.

El catastro urbano de Santiago: orígenes, desarrollo y aplicaciones, completa la colección de cinco volúmenes, inscritos dentro de la línea editorial de la Ilustre Municipalidad de Santiago, a través de su Dirección de Obras Municipales, textos que permiten la difusión de parte del quehacer de dicha dirección y aportan al conocimiento del espacio urbano de la comuna. 